\title{
高速液体クロマトグラフィーによる化学発光検出のための ピリミジン化合物のプレラベル化
}

\author{
吉田 滋 $^{\circledR}$, 浦上康司, 木藤正弘, 竹島繁男, 広瀬信吾 ${ }^{*}$
}

(1989 年 11 月 18 日受理)

\begin{abstract}
高感度な化学発光 HPLC でピリミジン化合物を定量するために蛍光標識体となるべきクマリン誘導 体を検索したところ 7-diethylamino-3-[4-(( iodoacetyl)amino)phenyl]-4-methylcoumarine（DCIA）が適 していた。このため DCIA によるピリミジン化合物のプレラベル化を行い, クロマトグラフィー特性 を調べると共に測定感度を上昇させることを試みた。 DCIA は無水炭酸カリウムと 18-crown-6 の共存 下アセトン中で目的物と反応させた。DCIA 誘導体の分離は逆相クロマトグラフィーで行い検出には化 学発光を用いた。化学発光は DCIA-Bis (2,4,6-trichlorophenyl)oxalate-過酸化水素系により発生させた. 反応条件，クロマトグラフィ一条件及び測定系なゼの最適化を行った結果，誘導体化された試料の検出

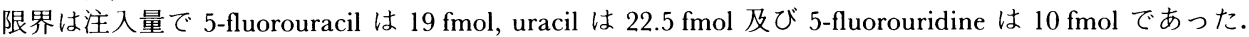
又，これらの薬物が血清 $1 \mathrm{ml}$ 当たり 1.25 250 $\mathrm{ng}$ 含まれる濃度範囲で検量線の直線関係が得られた。
\end{abstract}

\section{1 緒言}

ピリミジン及びその関連化合物の定量は核酸成分の研 究において重要であり, 微量で低濃度な試料を選択的 に，加高感度に定量する手段が求められている．これ らの目的のためにラジオイムノアッセイ ${ }^{1)}, \mathrm{GC}-\mathrm{MS}^{2)} や$ $\mathrm{UV}$ 検出法3)などによる定量法が報告されているが, 放 射化分析であったり, 高価な機器を必要としたり, 測定 感度が上昇しないなどの欠点を有している，そこでピリ ミジン化合物を実用的で高感度に分析するための手段と して HPLC の検出系に化学発光を利用することを試み た. 化学発光 HPLC の手段としては化学発光物質を標 識体之する分析法) (発蛍光性物質を蛍光標識体とする 方法)の 2 種が主として考えられる. 後者の方法は各種の 発蛍光性物質の中からピリミジン化合物と反応しやすい 化合物を選べるため今回の目的に適当であると考えた. 更に, 発蛍光性物質としてはカルボン酸のラベル化剂と して開発された，4-bromomethyl-7-methoxycoumarine $(\mathrm{Br}-\mathrm{Mmc})^{6}$, 4-bromomethyl-6,7-dimethoxycoumarine $(\mathrm{Br}-\mathrm{Mdmc})^{7)}$ 及び 7-diethylamino-3-[4-( (iodoacetyl) amino)phenyl] -4-methylcoumarine (DCIA) ${ }^{8)}$ の3 種を選 んだ.これらのうち $\mathrm{Br}-\mathrm{Mmc}$ と $\mathrm{Br}-\mathrm{Mdmc}$ はピリミジ ン化合物と反応することが既に知られており ${ }^{910)}$ 䖺光標
識体となり得るかを検討した．更に DCIA についても 同様の検討を加えた.

化学発光の測定には高感度分析が期待できるフォトン カウンティング法（PC 法）を応用することを試みた。 $\mathrm{PC}$ 法では光量子の検出を 1 秒当たりのカウント数 (cps) として測定するため, ややばらつきが大きくなる 欠点がある.このためデータを一度パーソナルコンピ ユーターに入力した後スムージング処理を行うことの効 果についても考察を行った.

以上のような目的のための試料として抗しゅよう剤と してよく用いられている 5-fluorouracil (5-FU)，5fluorodeoxy-uridine（FdUrd）及び uracil（Ura）を選び 化学発光検出 HPLC への応用を試みた.

\section{2 実験}

\section{$2 \cdot 1$ 試 薬}

5-FU, FdUrd, Ura, 18-crown-6, Bis (2,4,6-trichlorophenyl)oxalate (TCPO) などは半井テスクから購入し た. DCIA は Molecular Probes 社より, 又 $\mathrm{Br}-\mathrm{Mmc} や$ Br-Mdmc は Sigma 社より購入した。 その他の試薬や溶 媒はすべて特級を用いた。 コントロール血清はデン化生 研の臨床分析用のものを用い, ヒト血清は健常人ボラン ティアから得たものを使用した。

* 京都薬科大学 : 607 京都府京都市山科区御陵中内町 5 


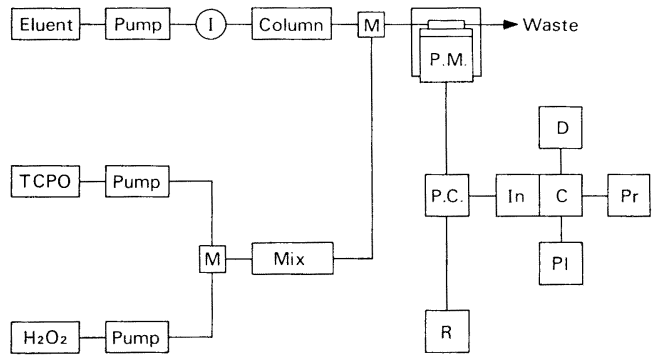

Fig. 1 Schematic diagram of the HPLC apparatus with chemiluminescence detection

I : injector; Mix : postcolumn mixer; P.M. : photomultiplier tube; P.C. : photon counter; $\mathrm{R}$ : recorder; In : interface; $\mathrm{C}$ : computer; $\mathrm{D}$ : display; $\mathrm{Pl}$ : plotter; $\mathrm{Pr}$ : printer

\section{$2 \cdot 2$ 装}

分析システムの既要を Fig. 1 に示した. 移動相のポ ンプとして島津 $\mathrm{LC}-4 \mathrm{~A}$, 又化学発光試薬用のポンプと して日本分光 BIP-I, 光電子增倍管は浜松ホトニクス R-585, フォトンカウンターは浜松ホトニクス G-767, パーソナルコンピューターは NEC PC-9801E, ディスプ レイは NEC PC-8853n, プリンターは島津 UP-2000, プ ロッターは EPSON HI80 をそれぞれ用いた。

\section{$2 \cdot 3$ クロマトグラフィー}

分離カラムには Nucleosil $5 \mathrm{C}_{18}$ (Nagel 製) を長さ 20 $\mathrm{cm}$ 内径 $0.4 \mathrm{~cm}$ のステンレスカラムにケムコ製のエコ ノパッカー CPP-085 を用いスラリー法によって充てん した．移動相にはアセトニトリルとリン酸緩衝液 $(4$ $\mathrm{mM}, \mathrm{pH} 7.5)$ の $1: 1$ 混液を用いた。流量は 0.6 $\mathrm{ml} / \mathrm{min}$ にした.

\section{$2 \cdot 4$ 化学発光用反応溶液}

$\mathrm{TCPO}$ は $4.4 \mathrm{mM}$ 酢酸エチル溶液とし, $\mathrm{H}_{2} \mathrm{O}_{2}$ は 1 M アセトン溶液とした。 それぞれの溶媒の流量を 0.7 $\mathrm{ml} / \mathrm{min}$ としてミキシングカラム (内径 $0.4 \mathrm{~cm}$, 長さ 20 $\mathrm{cm}$ のカラムに 200 400 メッシュの CPG ガラスを充 てん）で混合した後, 分離カラムからの溶出液と再度混 合した。

\section{$2 \cdot 5$ ラベル化反応}

ピリミジン化合物のアセトン溶液を $100 \mu \mathrm{l}$ 入れた 1 $\mathrm{ml}$ のネジロ試験管に DCIA 溶液 $(150 \mu \mathrm{g} / \mathrm{ml}$ アセトン) を $50 \mu \mathrm{l}, 18$-crown-6 溶液 $(15 \mu \mathrm{g} / \mathrm{ml}$ アセトン) を 50 $\mu \mathrm{l}$, そして無水炭酸カリウムを $500 \mu \mathrm{g}$ 加えた．その混合 溶液を 30 分間超音波かき混ぜしてラベル化反応を行っ た.

\section{$2 \cdot 6$ 血清試料の前処理}

標準試料はヒト血清に既知濃度の分析目的物を加えた ものを用いた. 前処理として, 血清 $0.5 \mathrm{ml}$ をメンブラ ンフィルター（ミリポア UFC3TGC00）に入れ遠心分 離機 $(1000 \mathrm{~g}, 20$ 分) で沪過した後, その洰液 $0.1 \mathrm{ml}$ 酶酸エチル $4 \mathrm{ml}$ を加えて 15 分間振り混ぜ抽出を行っ た.けん濁液を遠心分離 $(1000 \mathrm{~g}, 5$ 分）後, 有機相の $3.5 \mathrm{ml}$ を分取し窒素気流中で蒸発乾固し, アセトン 0.1 $\mathrm{ml}$ を加えて残留物を再溶解した溶液をラベル化反応に 供した。

\section{3 結果及び考察}

\section{$3 \cdot 1$ 化学発光用蛍光標墥化㓮の検討}

化学発光を生じさせやすい蛍光標識化剤の条件として 酸化電位の低いこと, 蛍光波長が長波長領域に存在する こと，又高い蛍光収率を有することなどが必要とされて いる1).このため $\mathrm{Br}-\mathrm{Mmc}, \mathrm{Br}-\mathrm{Mdmc}$ 及び DCIA の励 起, 蛍光波長亡蛍光収率を常法に従い求め Table 1 に 示した. 又 DCIA は他の 2 種と異なり電子供与基であ るアミノ基を有しているため酸化電位が低くなり, 励起 一重項状態へ移行させるエネルギーも小さくてすむと考 えられた.これらの結果は DGIA が Br-Mmc や Br$\mathrm{Mdmc} よ り$ 化学発光の蛍光標識化剤として有利なこと を示唆している.このため三者の化学発光を測定したと ころ DCIA にのみ発光が認められた. 又これらの蛍光 ラベル化剂でピリミジン化合物を誘導体化したものが化 学発光を生じたりあるいは消失する可能性が考えられ た.このため各誘導体の化学発光を測定したところ DCIA 誘導体にのみ発光が認められた。 そこで DCIA によるピリミジン化合物のラベル化のための最適条件を 検討した.

Table 1 Absorbance, fluorescence wavelengths and quantum yield for coumarin derivatives

\begin{tabular}{|c|c|c|c|}
\hline \multirow{2}{*}{$\begin{array}{l}\text { Derivatizing } \\
\text { agent }^{\text {a }}{ }^{2}\end{array}$} & \multicolumn{2}{|c|}{$\lambda_{\max } / \mathrm{nm}$} & \multirow{2}{*}{$Q^{\text {b) }}$} \\
\hline & Absorption & Emission & \\
\hline $\mathrm{Br}-\mathrm{Mmc}$ & 325 & 390 & 0.02 \\
\hline $\mathrm{Br}-\mathrm{Mdmc}$ & 340 & 420 & 0.24 \\
\hline DCIA & 403 & 475 & 0.51 \\
\hline
\end{tabular}

a) in $80 \%$ methanol ; b) quantum yield 


\section{$3 \cdot 2$ ラベル化条件の検討}

DCIA はアセトン溶液として用いた。この溶液は遮光 下 $0 \sim 3^{\circ} \mathrm{C}$ で保存すれば 1 週間は安定であった.

まず反応溶媒の検討を行った。 5-FU, FdUrd 及び Ura どをアセトン,.ジメチルホルムアミド (DMF), アセトニトリル $\left(\mathrm{CH}_{3} \mathrm{CN}\right)$ 及びジメチルスルホキシド （DMSO）に溶解し，実験の部のラベル化法に従ってラ ベル化した. その結果アセトン溶媒中で最も反応が進行 し, DMF や $\mathrm{CH}_{3} \mathrm{CN}$ 中に比べ 1.5 4 倍の発光強度と なった. 又 DMSO 中で反応させるとブランクピークの 増加が目立った。以上の結果より反応溶媒としてはアセ トンを選んだ。

次に反応温度について検討した. 室温, $40^{\circ} \mathrm{C}$ 及び還 流下で各 30 分反応させたところ, 室温と $40^{\circ} \mathrm{C}$ では ピーク高さに変化がなかったが還流したものでは DCIA の分解によるものと推定される大きなブランクピークが 認められた。一方 5-FU や Ura では DCIA と 1:1 や $1: 2$ の割合でラベル化される可能性があり検討した.

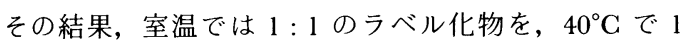
時間振り混ぜると $1: 1$ と $1: 2$ の混合物を生成するこ とが分かった. 1:2 のラベル化体を生成させるには $70^{\circ} \mathrm{C}$ で還流させる条件が必要であった。この1:2の ラベル化物の発光強度は $1: 1$ のそれよりも高かったが
前述の大きなブランクピークによる妨害を避けられなか った.

更に 18-crown-6 が存在する場合としない場合の結果 を比較した５-FU，FdUrd 及び Uraに関して調べたと ころ 18-crown-6 が存在しないとそれぞれ 57\%，20\%， $17 \%$ もピーク高さが減少し, 触媒としての有用性が示 された. 以上の結果より Fig. 2(A) に示した化学発光 に必要な蛍光標識化㓮として（B）で示したラベル化条 件で生成するラベル化体を用いることにした。

\section{$3 \cdot 3$ 化学発光の測定}

化学発光 HPLC に適した測定条件の検討を行った. まず移動相としてメ夕ノール系とアセトニトリル系とを 比較したところ後者を用いるほうが発光強度で約 10 倍 高くなった。 又移動相に対するTCPO と $\mathrm{H}_{2} \mathrm{O}_{2}$ の混合割 合を検討した結果, 両者共に $0.7 \mathrm{ml} / \mathrm{min}$ とした. 更に 混合後は最短距離（約 $3 \mathrm{~cm}$ ）でセルへ到達するように した. 発光をとらえる光電子増倍管に対する負荷電圧に ついても検討した. 負荷電圧を $500 \mathrm{~V} \sim 800 \mathrm{~V}$ まで変化 させたところその電圧を上昇させるに従って発光強度は 高く測定できたが，バックグラウンドも同様に上昇して きた.このため $S / N$ 比と負荷電圧との関係を求めたと ころ $700 \mathrm{~V}$ で最大の $S / N$ 比を示すことが分かった．以

(A)<smiles>O=C(Oc1c(Cl)cc(Cl)cc1Cl)C(=O)Oc1c(Cl)cc(Cl)cc1Cl</smiles>

TCPO

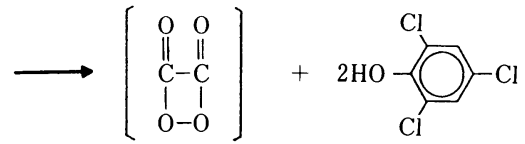

1,2-dioxethanedione $\left[\begin{array}{cc}\mathrm{O} & \mathrm{O} \\ \stackrel{\|}{\|} & \| \\ \mathrm{C} & -\mathrm{C} \\ \mathrm{O} & \stackrel{l}{\mathrm{O}}\end{array}\right]+$ Fluorophore $\longrightarrow$ Fluorophore $+2 \mathrm{CO}_{2}$ Fluorophore $\longrightarrow$ Light + Fluorophore

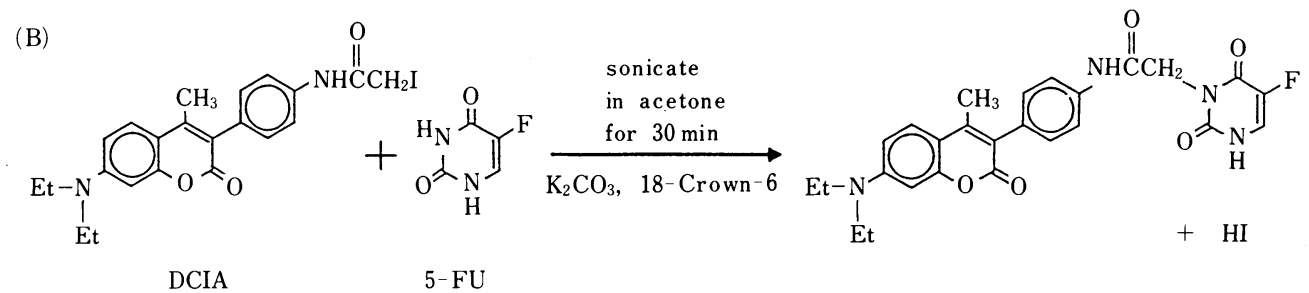

Fig. 2 Peroxyoxalate chemiluminescence reaction 
上の最適な結果に基づいて 5-FU, FdUrd 及び Ura の各 $50 \mathrm{ng}$ を $0.2 \mathrm{ml}$ のアトン中でラベル化し化学発光 HPLC で検出したクロマトグラムを Fig. 3 に示した.

\section{$3 \cdot 4$ スムージング効果}

$\mathrm{PC}$ 法は非常に高感度な検出法であるが $\mathrm{cps}$ 又は $\mathrm{cpm}$

(A)

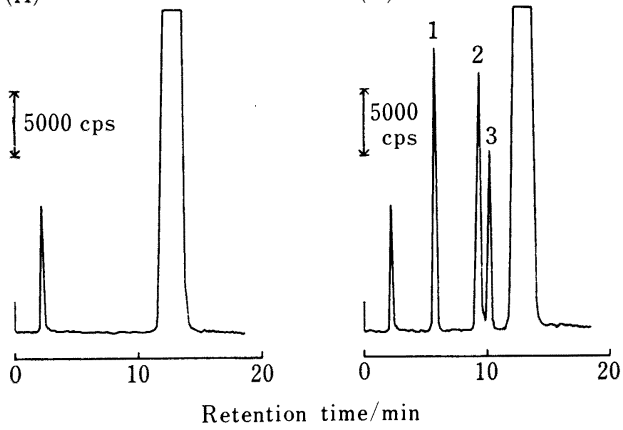

Fig. 3 Chromatogram of chemiluminescent derivatives of a standard mixture of pyrimidine compounds

(A) blank; (B) sample (1:5-FU, 2: Ura, 3 : FdUrd). 5-FU, Ura, FdUrd: each $50 \mathrm{ng}$; DCIA : $10 \mu \mathrm{g} ; 18$-crown-6 : $1 \mu \mathrm{g} ; \mathrm{K}_{2} \mathrm{CO}_{3}: 500$ $\mu \mathrm{g}$ in $0.2 \mathrm{ml}$ acetone; Mobile phase : $\mathrm{CH}_{3} \mathrm{CN}-4$ $\mathrm{mM}$ phosphate buffer $=1: 1$; Flow rate: 0.6 $\mathrm{ml} / \mathrm{min}$
で測定するために測定値のばらつきが大きく, 従って $S / N$ 比が悪くなるのが最大の欠点となっている.この 対応策としてスムージングを行い検出限界を向上させる ことを試みた．スムージングの方法としては多項式適合 法 $^{12)}$ を用いた。この方法は測定波形が各サンプル点の 近傍で多項式曲線で表現できると仮定して，この近傍内 で最小二乗法規範に基づき測定波形と多項式曲線を適合 させる方法である. 今回は 1 秒ごとに得られる PC の データをすべてインターフェイスを介して一度ディスク に収めた. 測定終了後収められたデータを呼び出し，二 次・三次多項式適合法による演算処理をした後, ディス プレイに表示した。なお，適合法に必要な平滑化演算に は Savitzky-Golay 法 $^{13)}$ によるコンボリューションを用 いた. Fig. 4(A) にはヒト血清中の 5-FU, FdUrd 及び Ura を測定するためのクロマトグラムをスムージング しない状態で示した. それぞれの濃度は注入量で 5-FU $10 \mathrm{pg}(80 \mathrm{fmol})$, Ura $50 \mathrm{pg}(450 \mathrm{fmol})$ 及び FdUrd $10 \mathrm{pg}$ $(40 \mathrm{fmol})$ である.この状態では $S / N$ が悪すぎて定量 に用いられない.Fig. 4(B) は（A）の感度を 5 倍に拡 大し测定したものであり $S / N$ 比の悪さは同様である. そこでこのクロマトグラムを 15 点平滑化を行ったとこ ろ（C）のようになり，検量線の一部として十分使用で きる状態となった. 平滑化を行う点の数の検討を行った ところ 15 点以下ではスムージングの効果が小さく, 逆 に 15 点以上では平滑化されすぎてピーク高さの減少と
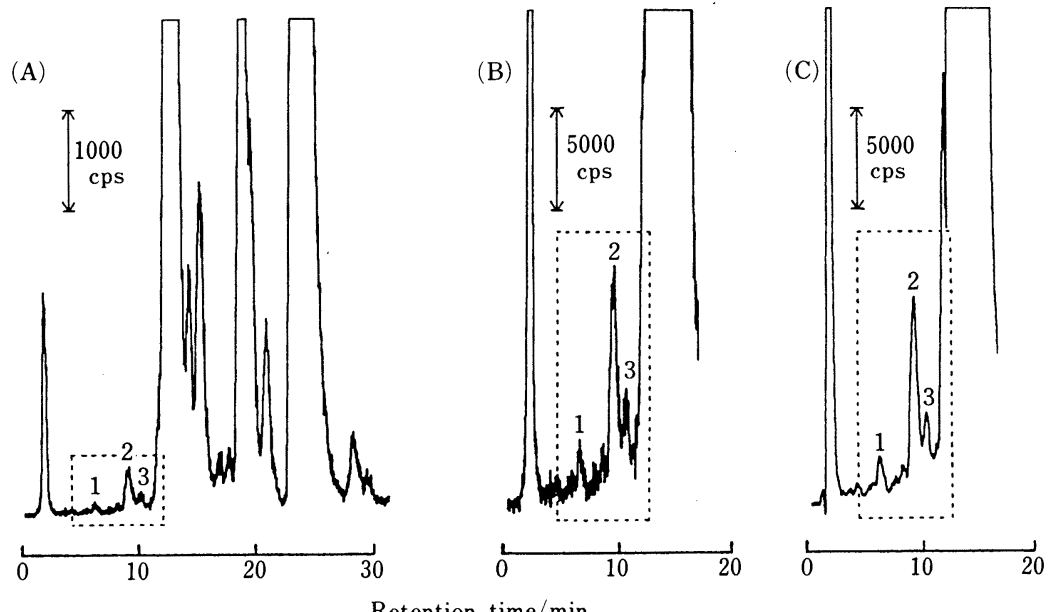

Retention time/min

Fig. 4 Smoothing effect by simplified least squares procedures

(A) (B) no treatment; (C) convoluted chromarogram (convolution number: 15). 1:5-FU; $2:$ Ura; $3:$ FdUrd. 5-FU, FdUrd : $500 \mathrm{pg}$; Ura : $2.5 \mathrm{ng}$; DCIA : $25 \mu \mathrm{g}$; 18-crown-6:2.5 $\mu \mathrm{g} ; \mathrm{K}_{2} \mathrm{CO}_{3}: 500 \mu \mathrm{g}$ in $0.2 \mathrm{ml}$ acetone 
Table 2 Reproducibility of pyrimidine compounds in serum by chemiluminescence HPLC

\begin{tabular}{cccc}
\hline \multirow{3}{*}{ No. } & \multicolumn{3}{c}{ Recovery, \% } \\
\cline { 2 - 4 } & 5-FU & Ura & FdUrd \\
\hline 1 & 75.7 & 83.2 & 82.0 \\
2 & 75.4 & 82.1 & 80.9 \\
3 & 75.9 & 85.6 & 81.2 \\
4 & 79.8 & 83.5 & 77.6 \\
5 & 76.7 & 82.1 & 81.3 \\
m.v. & 76.7 & 83.3 & 80.6 \\
s.d. & 1.80 & 1.43 & 1.72 \\
R. S. D., \% & 2.34 & 1.72 & 2.14 \\
\hline
\end{tabular}

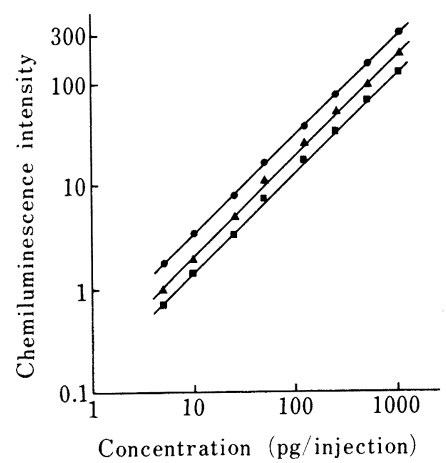

Fig. 5 Relationship between chemiluminescence intensity and amount of each pyrimidine compound

DCIA : $10 \mu \mathrm{g} ; 18$-crown-6:1 $\mu \mathrm{g} ; \mathrm{K}_{2} \mathrm{CO}_{3}: 500$ $\mu \mathrm{g}$ in $0.2 \mathrm{ml}$ acetone. (O) Ura : $Y=0.301 X-$ $0.030(r=0.9993) ;(\boldsymbol{\Delta})$ FdUrd : $Y=0.298 X-$ $0.031(r=0.9991) ;(\square) 5-\mathrm{FU}: Y=0.299 X-$ $0.029(r=0.9994)$

なって現れた. 以上の結果より, PC 法にスムージング 法を適用することは大変効果的であり無処理の場合と比 べ検出限界を約 10 倍上昇させることが可能となった。

\section{$3 \cdot 5$ 回収試験と検量線}

健常人血清 $1 \mathrm{ml}$ に 5 -FU, FdUrd, Ura の各 $250 \mathrm{ng}$ を 添加して分析した結果と標準物質を用いた分析の結果を 比較し，回収率として Table 2 に示した。 又再現性に ついても同時に Table 2 に示した. 両者とも良好な結 果が得られ, 特に回収率については従来法より高い值と なった ${ }^{14)}$. 更にこれらの薬物を血清 $1 \mathrm{ml}$ 当たり 1.25 $\mathrm{ng} \sim 250 \mathrm{ng}$ の濃度範囲で添加し, ラベル化処理後の
溶液 $4 \mu \mathrm{l}$ ずつを注入（注入量にして 5-FU: 38 fmol $\sim 7.8 \mathrm{pmol}$, Ura : $45 \mathrm{fmol} \sim 9.0 \mathrm{pmol}$, FdUrd : $20 \mathrm{fmol}$ $\sim 4.0 \mathrm{pmol}$ に相当する) して得られた検量線を Fig. 5 に示した. 今回開発した化学発光 HPLC-PC 検出法多項式適合スムージング法による定量法の検出限界は $S / N$ 比を 2 とした場合，注入量で 5-FU : $19 \mathrm{fmol}$, Ura : $22.5 \mathrm{fmol}$, FdUrd : $10 \mathrm{fmol}$ であった.これらの值は従来 の蛍光ラベル化法9)10)14) に比べ約 20４0 倍の感度上昇 に相当し, その高感度性が注目される結果となった。

\section{文献}

1) T. W. Bruice, C. Garrett, Y. Wataya, D. V. Santi : "Methods in Enzymology", Vol. 64, p. 125 (1980), (Academic Press, Inc., London).

2) P. L. Stetsom, J. Maybaum, U. A. Shukla, W. D. Ensminger: J. Chromatogr., 375, 1(1986).

3) F. P. LaCreta, W. M. Williams : J. Chromatogr., 414, 197 (1987).

4) E. H. J. M. Jansen, R. H. Van Den Berg, R. Both-Miedema, C. Eukelaur-Willemsen, G.Zomer : Anal. Chim. Acta, 205, 175 (1988).

5) M. Tod, R. Farinotti, G. Mahuzier : Anal. Chim. Acta, 217, 11 (1989).

6) W. Dünges : Anal. Chem., 49, 442 (1977).

7) R. Farinotti, J. Bourson, S. Kirkiacharian, B. Valenr, G. Mahuzier: J. Chromatogr., 269, 81 (1983).

8) T. O. Sippel : J. Histochem. Cytochem., 29, 314 (1981).

9) S. Yoshida, S. Hirose, M. Iwamoto: J. Chromatogr., 383, 61 (1986).

10) S. Yoshida, T. Adachi, S. Hirose : Microchem. J., 39, 351 (1989).

11 ) C. L. R. Gatherall, T. F. Palmer, R. B. Cundall : J. Chem. Soc., Fraday Trans. 2, 80, 837 (1984).

12) A. Savitzky, M. J. E. Golay: Anal. Chem., 36, 1627 (1964).

13) H. H. Madden : Anal. Chem., 50, 1383 (1978).

14) M. Yamaguchi, M. Nakamura, N. Kuroda, Y. Ohkura : Anal. Sci., 3, 75 (1987).

\section{诧}

Precolumn derivatization of pyrimidine compounds for chemiluminescence detection in HPLC. Shigeru Yoshida, Koji Urakami, Masahiro Kito, Shigeo Takeshima and Shingo Hirose (Kyoto Pharmaceutical University, 5, Misasagi, Yamashina-ku, Kyoto-shi, Kyoto 607)

Precolumn derivatization with 7-(diethylamino)-3-[4((iodoacetyl)amino)phenyl]-4-methylcoumarin (DCIA) is utilized to improve the chromatographic and detection properties of pyrimidine compounds. The reagent reacts with pyrimidine compounds in acetone in the presence of crystalline anhydrous potassium carbonate and 18-crown- 
6. The DCIA derivatives are separated using reversedphase LC and detected using chemiluminescence generated by the reaction of DCIA-Bis(2,4,6-trichlorophenyl)oxalate-hydrogen peroxide. After optimization of the reaction, chromatographic and detection conditions, the limits of the detection were $19 \mathrm{fmol}$ for 5-fluorouracil, $22.5 \mathrm{fmol}$ for uracil, and $10 \mathrm{fmol}$ for 5-fluorodeoxyuridine per injection, with a linearity of two orders of magnitude. This chemiliminescence HPLC technique is useful for the simultaneous determination of 5-fluoropyrimidines, used as a chemotherapeutic, in small volumes of serum.

(Received Novemver 18, 1989)

\section{Keyword phrases}

chemiluminescence HPLC; precolumn derivatization; pyrimidine compounds; uracil; 5-fluorouracil; 5fluorodeoxyuridine. 